\title{
Compressibility Characteristics of Compacted Clay Treated with Cement, Peat Ash and Silica Sand
}

(Ciri Kebolehmampatan Tanah Liat Terpadat Dirawat dengan Simen, Abu Gambut dan Pasir Silika)

\author{
SEYEDESMAEIL MOUSAVI* \& LEONG SING WONG
}

\begin{abstract}
This paper investigates the compressibility characteristics of compacted clay treated with cement, peat ash and silica sand.For this purpose, one dimensional consolidation tests were conducted to determine the soil consolidation properties. The test specimens were trimmed from the compaction test specimen. The $1 D$ consolidation test specimen was subjected to the normal pressures of 2.5, 5, 10,20,40,80 and $160 \mathrm{kPa}$ in sequence on the test specimen which was saturated with distilled water. At the end of the loading period of $80 \mathrm{kPa}$, the vertical load was removed and the specimen was allowed to expand for $24 \mathrm{~h}$ for the purpose of evaluating of its swelling behavior. The results showed that void ratio of the soil specimens decreased with increasing effective normal pressure. The laboratory investigation clearly demonstrates that, settlement is as the compression of a soil specimen due to vertical loading applied at the top surface of the $1 D$ consolidation test specimen. It was concluded that, the compression settlement of the stabilized soil with the binder composition of $18 \%$ cement, $2 \%$ peat ash and 5\% silica sand improved by almost 1.3-fold. A notable discovery is the suitability of the stabilized soil for road embankment and low lying marginal area for foundation works; also solving the environmental problems in relation to peaty ground. However, sufficient laboratory and field testing are required.
\end{abstract}

Keywords: Compressibility; road embankment; soft clay; $1 D$ consolidation

\section{ABSTRAK}

Kertas ini mengkaji ciri kebolehmampatan tanah liat terpadat yang dirawat dengan simen, abu gambut dan pasir silika. Bagi tujuan ini, satu ujian penyatuan dimensi telah dijalankan untuk menentukan sifat konsolidasi tanah. Spesimen ujian telah dipotong daripada spesimen ujian pemadatan. Spesimen ujian konsolidasi $1 \mathrm{D}$ adalah tertakluk kepada tekanan normal 2.5, 5, 10, 20, 40, 80 dan $160 \mathrm{kPa}$ dalam turutan ujian spesimen yang telah ditepu dengan air suling. Pada akhir tempoh pemuatan $80 \mathrm{kPa}$, beban menegak telah dihapuskan dan spesimen itu dibiarkan untuk berkembang selama 24 jam bagi tujuan menilai tingkah laku pembengkakan. Hasil kajian menunjukkan bahawa nisbah batal bagi spesimen tanah menurun dengan peningkatan tekanan normal yang berkesan. Kajian makmal dengan jelas menunjukkan bahawa penyelesaian adalah seperti pemampatan spesimen tanah yang disebabkan oleh beban menegak yang diguna pakai di atas permukaan spesimen ujian pengukuhan 1D. Ia menunjukkan bahawa penyelesaian mampatan tanah stabil dengan komposisi pengikat 18\% simen, $2 \%$ abu gambut dan 5\% pasir silika meningkat sebanyak hampir 1.3-lipatan. Satu penemuan yang ketara ialah kesesuaian tanah stabil bagi tambak jalan dan kawasan marginal rendah untuk kerjakerja asas; juga menyelesaikan masalah alam sekitar berkaitan tanah gambut. Walau bagaimanapun, ujian makmal dan lapangan adalah perlu.

Kata kunci: Kebolehmampatan; konsolidasi 1D; tambak jalan; tanah liat lembut

\section{INTRODUCTION}

Infrastructural development is a major challenge for many developing countries, most of which are located around the tropics. With regard to such developments, coastal regions are the major areas receiving impetus, since ports and highways are located on it. The coastal areas consist of soft clay, peat and organic soil. Generally, the soft clay deposited in the Southeast Asian countries such as Malaysia has ranged from very shallow to a depth of about $40 \mathrm{~m}$ (Taha et al. 2000). Organic soils have been widely interpreted as product of tropical weathering and are widespread around the tropics (Eberemu 2015). According to Bujang et al. (2011), the organic clay such as peat have a high content of organic matter. Peat is an acidic soil with a $\mathrm{pH}$ value below than 7 . It has three different types, namely fibric, hemic and sapric. Utilization of waste materials such as peat has been the focus of research lately in the field of geotechnical engineering for economic, environmental and technical reasons (Mousavi \& Wong 2015; Wong et al. 2013). Besides, soft clay is problematic due to its poor mechanical behavior; particularly in some cases the soil properties in the immediate vicinity of the construction work such as road embankment may not meet the required specifications. Such soils need to be improved so as to meet the geotechnical requirements of 
the correspondent engineering application (Eberemu 2015). Previous studies have proven that it is viable to use waste materials as partial cement replacement materials to stabilize soft soils (Baghdadi 1990; Collins \& Emery 1983; Purwana \& Nikraz 2013; Wong et al. 2013; Yilmaz \& Ozaydin 2013). According to Isaia et al. (2003) and Wong et al. (2013), pozzolanic materials have many advantages such as $\mathrm{CO}_{2}$ emission reduction when they used as replacement materials for Portland cement. In essence, utilization of peat ash as a partially substitute material for cement in stabilized soil provides a solution for $\mathrm{CO}_{2}$ emission reduction, which in turn can reduce energy consumption of cement production and global warming as well. Abou-Taleb et al. (1995) have stipulated that cement industry generates dust during its production and cement dust causes damage to health and the environment. Velosa and Cachim (2009) have estimated that $5 \%$ of $\mathrm{CO}_{2}$ emissions is related to cement industries. Rehan and Nehdi (2005) have reported that from the de-carbonation of limestone and burning of fossil fuels about 1 tonne of $\mathrm{CO}_{2}$ is emitted from each tonne of cement. Therefore, it is important to utilize waste materials to minimize the amount of cement and save the amount of input cement. The research to find alternative raw materials and to reduce energy consumption and protect the environment in cement production is of global concern (Yilmaz \& Ozaydin 2013). With respect to this, peat ash was obtained from fresh peat after burning in a muffle furnace (ASTM D2974-14). It is the aimed of this study to utilize peat ash as a supplementary material for cement in the production of sustainable soil due to economic and environmental reasons. The material characterization of peat ash in term of chemical composition was explored. Basically, consolidation is regarded as the response of fine grained soil to impose load. The consolidation theory presented by Terzaghi (1943) and Terzaghi and Peck (1967) plays a key role in geotechnical industries, particularly in slope stability analyzing and laboratory testing (Taha et al. 2000). According to Schiffman et al. (1984), consolidation concept is fundamental to the practice of geotechnical engineering where the interaction of soil and water dominates. The primary objective of this research work was to investigate the ability of cement and peat ash to reduce the compression settlement of stabilized soil so that a suitable stabilized soil as a shallow foundation for road embankment can be achieved.

\section{EXPERIMENTAL DESIGN}

\section{MATERIALS USED}

Soil The soil sample is soft clay collected from Taman Wetlands, in the area of Putrajaya of the state of Selangor in Malaysia at about $1.5 \mathrm{~m}$ depth. Initial observation on the soil showed that the soil is soft and sticky. For the soil classification purpose, the natural soil sample was oven dried at a temperature of $105^{\circ} \mathrm{C}$. The soil was characterized by performing basic tests required for the soil classification. The basic properties of the natural soil sample are: natural moisture content $=45 \%$; liquid limit $=56 \%$; plastic limit $=24 \%$; plasticity index $=32 \%$; liquidity index $=66 \% ; \mathrm{pH}$ $=7.1$; specific gravity $=2.46$ and USCS classification $=$ CLAY of high plasticity $(\mathrm{CH})$. Based on the results of sieve analysis, the soil sample is composed of $62 \%$ clay, $23 \%$ sand and 15\% silt (Mousavi \& Wong 2015).

Cement The type of cement for the study is ordinary Portland cement (OPC), equivalent to ASTM type I, of YTL Company.

Peat ash The sampled peat from Klang, Selangor, Malaysia is first oven dried at $105^{\circ} \mathrm{C}$ for $24 \mathrm{~h}$. Then the oven dried peat was burnt in a muffle furnace at a temperature of $440^{\circ} \mathrm{C}$ for $4 \mathrm{~h}$ (ASTM D2974-14). Due to Loss on Ignition (LoI), the peat ash was produced after burning in the muffle furnace (Mousavi \& Wong 2015).

Silica sand Locally available silica sand was used for the research work. For the purpose of modifying grain size distribution of the soil sample, silica sand was used as a grading modifier.

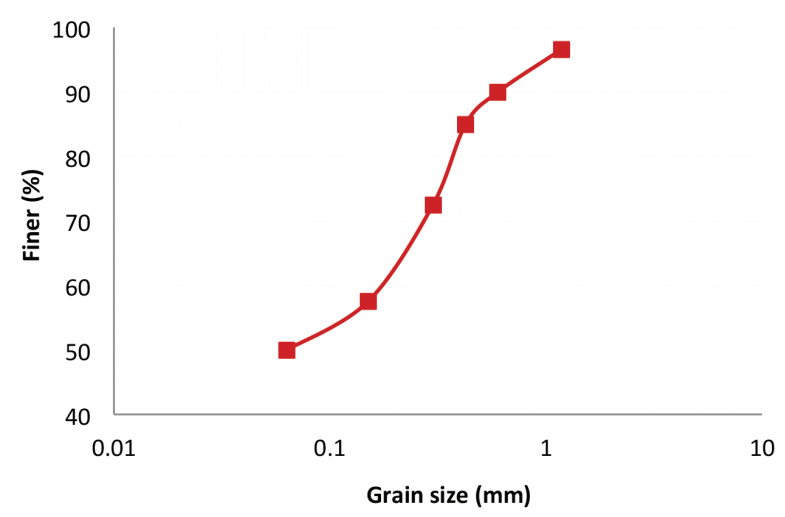

FIGURE 1. Grain size distribution curve of the silica sand

The chemical composition of the materials by the percentage of the total chemical composition's weight from $\mathrm{X}$-ray Fluorescence (XRF) tests are also indicated in Table 1 , according to which, in peat ash the sum of silica $\left(\mathrm{SiO}_{2}\right)$ and alumina $\left(\mathrm{AL}_{2} \mathrm{O}_{3}\right)$ is $72.6793 \%$ of the total chemical composition. This is attributed to the pozzolanic properties of the peat ash as justified by Wong et al. (2013).

TABLE 1. Chemical composition of the additives for soil stabilization under study

\begin{tabular}{lc}
\hline Component & Concentration $(\%)$ \\
\hline $\mathrm{Al}_{2} \mathrm{O}_{3}$ & 22.7316 \\
$\mathrm{SiO}_{2}$ & 49.9477 \\
$\mathrm{SO}_{3}$ & - \\
$\mathrm{Alkali}\left(\mathrm{K}_{2} \mathrm{O}, \mathrm{Na}_{2} \mathrm{O}\right)$ & 2.8794 \\
$\mathrm{CaO}$ & 5.5818 \\
$\mathrm{Fe}_{2} \mathrm{O}_{3}$ & 17.7265 \\
Others & 1.133 \\
\hline
\end{tabular}




\section{TESTING PROGRAM}

The aim of $1 \mathrm{D}$ consolidation test is to evaluate the compressibility characteristics of the untreated and stabilized soil specimens. The test is based on the standard ASTM D2435. According to ASTM D2435, in saturated cohesive soils, the effect of loading is to squeeze out pore water; this process is called consolidation. Oedometer (1D consolidation) tests were conducted to determine the soil consolidation properties. The untreated soil specimen was trimmed from the compaction test specimen with brass cutter ring with a diameter of $50 \mathrm{~mm}$ and a height of 20 $\mathrm{mm}$. To reduce the side friction between the brass ring and soil specimen, the inner surface of the ring was slightly lubricated. Filter papers and porous stones were positioned at the top and bottom faces of the soil specimen (Mousavi $\&$ Wong 2015). The oedometer cell was positioned in the loading frame and normal pressures of 2.5, 5, 10, 20,40, 80 and $160 \mathrm{kPa}$ were applied in sequence on the test specimen which was saturated with distilled water. Evaporation of water from the consolidation cell was minimized by placing fitting metal jackets on top of the cell. The test specimens were allowed to cure overnight for possible reactions among the soil sample, cement and peat ash. The consolidation test was carried out at a room temperature of $26 \pm 2^{\circ} \mathrm{C}$. Conventional consolidation test according to the ASTM standard was carried out after equilibrium had been attained as indicated by the nearly constant readings on the vertical dial gauge. The load increment applied was twice larger than the previous load. The duration of each load was 24 h (Horpibulsuk et al. 2011).

\section{SPECIMEN PREPARATION}

For the purpose of soil stabilization, three test specimens with the binder compositions of: $18 \%$ cement, $2 \%$ peat ash; $13.5 \%$ cement, $6.5 \%$ peat ash; and $9 \%$ cement, $11 \%$ peat ash were tested under standard Proctor compaction tests. For each test specimen, 5\% silica sand was also added as grain size modifier. The test specimen with the highest maximum dry density ( $18 \%$ cement, $2 \%$ peat ash and 5\% silica sand) was chosen as an ideal mix design. The compacted soil specimen with the ideal mix design was trimmed to required size for the purpose of $1 \mathrm{D}$ consolidation tests. After each compression test, final moisture content and final void ratio of the test specimen were determined. Each vertical load was held constant for $24 \mathrm{~h}$ before addition of the next loading increment. At the end of the loading period of $80 \mathrm{kPa}$, the vertical load was removed and the specimen was allowed to expand for $24 \mathrm{~h}$ for the purpose of evaluation its swelling behavior (ASTM D2435). The coefficient of permeability, compressibility index, coefficient of volume compressibility and coefficient of consolidation for each load increment were determined. The compression can be divided into elastic compression, primary consolidation and secondary compression. For each compression graph, the time to reach $90 \%$ consolidation was determined by root of time method. For the purpose of the reproducibility of the laboratory test results, 1D consolidation tests were repeated on 4 out of the 24 specimens randomly. The differences between the 2 tests were within below $10 \%$. The physical properties of the untreated and stabilized soil specimens under 1D consolidation test are tabulated in Table 2. It is worth noting that determination of the final water content of the soil specimen was necessary for the calculation of its final and initial void ratios. Effect of stabilization with cement and peat ash on liquid limit of the soil specimens is illustrated in Figure 2.

\section{RESULTS AND DISCUSSION}

The relationships between consolidation settlement and elapsed time of untreated soil specimens under various normal stresses are illustrated in Figure 3. The root time method was employed to calculate the time to reach $90 \%$ consolidation of the soil specimen. It is observable from the graphs that compression settlement increased with increasing consolidation pressure. All the graphs in Figure 3 depict that the soil specimen was subjected to compression

TABLE 2. Physical properties of 1D consolidation test specimens

\begin{tabular}{lcc}
\hline Description & Untreated soil & Stabilized soil \\
\hline Diameter of specimen $(\mathrm{mm})$ & 50 & 50 \\
Height of specimen $(\mathrm{mm})$ & 20 & 20 \\
Volume of specimen $\left(\mathrm{cm}^{3}\right)$ & 39.3 & 39.3 \\
Mass of specimen ring $(\mathrm{g})$ & 61 & 61 \\
Mass of specimen ring + specimen $(\mathrm{g})$ & 127 & 132 \\
Mass of specimen $(\mathrm{g})$ & 66 & 71 \\
Mass of solid $(\mathrm{g})$ & 56.65 & 59.89 \\
Volume of solid $\left(\mathrm{cm}^{3}\right)$ & 23 & 24.4 \\
Volume of voids $\left(\mathrm{cm}^{3}\right)$ & 16.24 & 14.92 \\
Initial void ratio $\left(\mathrm{e}_{0}\right)$ & 0.71 & 0.61 \\
Degree of saturation before the test $(\%)$ & 56.5 & 75.6 \\
Initial moisture content $(\%)$ & 16 & 21 \\
Moisture content at the end of the test $(\%)$ & 25 & 22 \\
Final void ratio $\left(\mathrm{e}_{1}=\omega_{1} \times \mathrm{G}_{\mathrm{s}}\right)$ & 0.61 & 0.54 \\
\hline
\end{tabular}




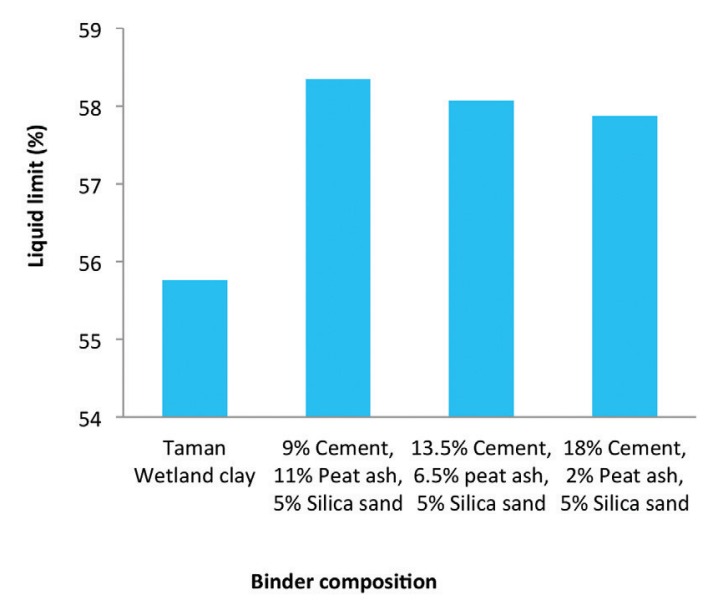

FIGURE 2. Liquid limit of the test specimens after $24 \mathrm{~h}$

as a result of a loading application. The volume of the soil specimen reduced consistently with each addition of consolidation stress. Based on the method of evaluation, it is evident from Figure 3 that the soil compressibility was predominated by primary consolidation. It is important to note that primary consolidation was largely due to the dissipation of excess pore water pressure from the soil. Basically, settlement occurred due to time passage, applied vertical load and pore water dissipating out from the soil specimen. According to Maio et al. (2004), it occurs due to expulsion of pore water pressure from the voids of a saturated soil. The deformation is due to squeezing of water from the pores leading to rearrangement of soil particles. The movement of pore water depends on the permeability and dissipation of pore water pressure. It is important to stress that beside the consolidation phenomenon, the test specimen was subjected to hydration process due to the cementation of the soil particles. This resulted in a reduction of settlement in the stabilized soil when compared to that of untreated soil. It can also be observed from Figure 3 that settlement of the test specimen increased with consolidation time. This contributed to the reduction in the volume of the test specimen.
Based on the data that obtained from 1D consolidation tests, the graphs of void ratio versus normal stress for the ideal mix design and untreated soil specimen were plotted in Figure 4. The values of void ratio were recorded before the application of the next pressure increment. The data collected from the tests enabled changes in void ratio to be corresponded to changes in effective normal stress. It is clearly seen in Figure 4 that the void ratio of the soil specimen decreased with increasing normal stress. It is due to the dissipation of pore water from the voids of the soil specimens with elapsed time that reduced the voids. Besides, stabilization of the soil with cement and peat ash contributed to the strong interparticle bonding due to cementation products and binding effect of cement.

The relationship between void ratio and vertical effective stress of the soil sample on a semi logarithmic scale from 1D consolidation tests is shown in Figure 5. As noticed in Figure 5, the void ratio of the soil specimen declined with increasing effective normal stress. This is largely attributed to the soil consolidation settlement of which volume change was significant as a result of the expulsion of excess pore water pressure from the soil. Since the compression path (from points A to B) moves along the normal compression line ( $\mathrm{NCL}$ ), the soil is considered as normally consolidated clay. Besides, the value of pre-consolidation stress $\left(\sigma^{\prime}{ }_{p c}\right)$ or maximum past pressure was estimated using Casagrande empirical graphical method through analysis on the e/log $\sigma^{\prime}$ curve. From the soil mechanic books, pre-consolidation stress is defined as the highest historical stress experienced by the soil. It can be due to natural depositional loading or during site condition. As shown in Figure 5, point M is located at the point of maximum curvature. By applying Casagrande method of graphical interpretation, the pre-consolidation pressure was determined to be $45 \mathrm{kPa}$ for both untreated and stabilized clay specimens.

According to ASTM D2435, the coefficient of volume compressibility $\left(m_{v}\right)$ represents the amount of change in unit volume due to a unit increase in effective stress. Normally, the volume change behavior of clay soil is

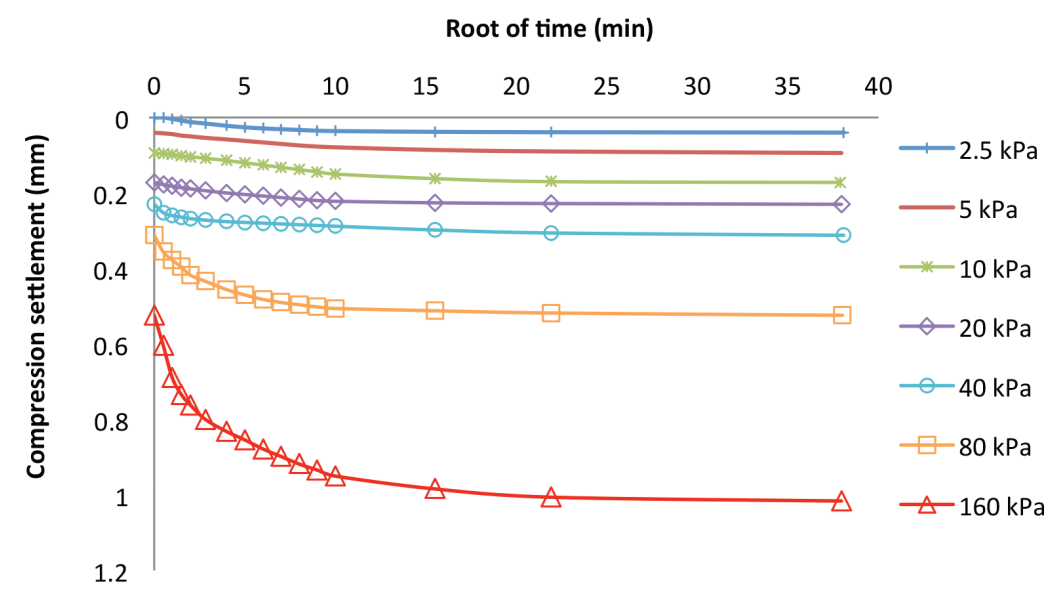

FIGURE 3. Settlement-time relationships under various normal stresses 


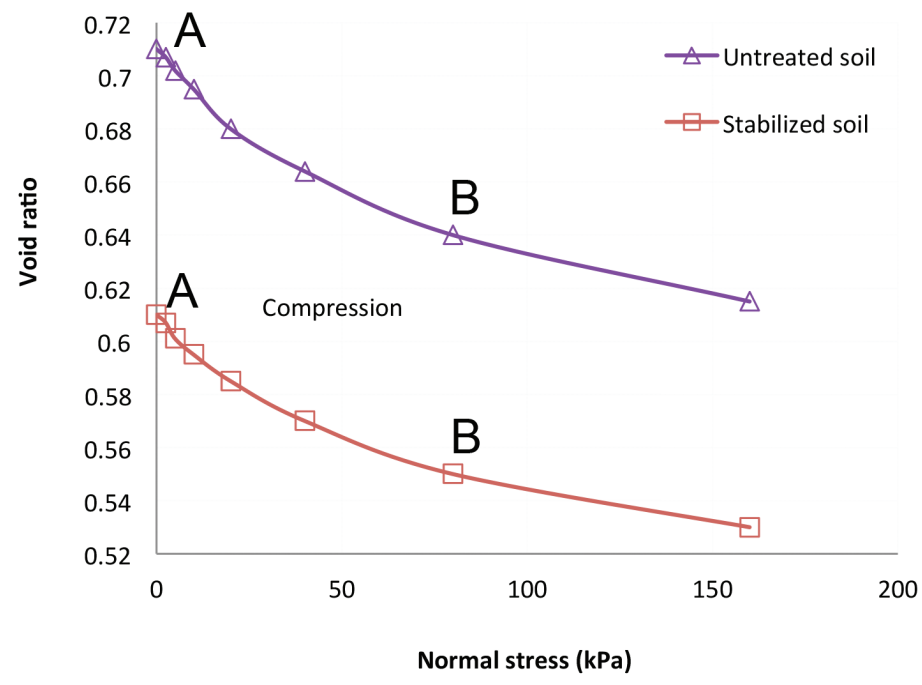

FIGURE 4. Variations of void ratio versus normal stress of (a) untreated and (b) stabilized soil

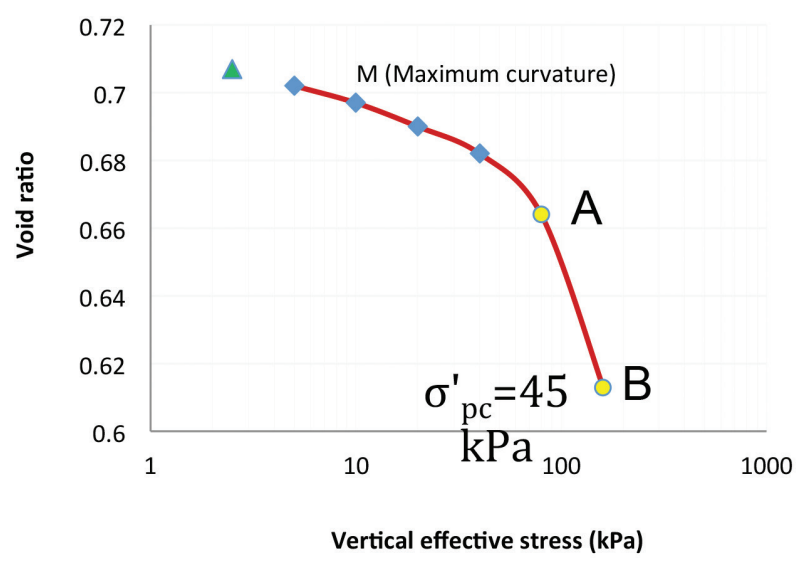

FIGURE 5. e / Log $\sigma^{\prime}{ }_{n}$ curve of the untreated clay

due to the effect of complex interactions between the soil particles and pore fluid. Mineral types, binder types, liquid composition of pores, void ratio and normal stress level can be affected by the type of interactions (Maio et al. 2004). Based on the values of the coefficient of volume change, the $m_{v} / \sigma$ ' curve was plotted as shown in Figure 6 . The curve was plotted with the values of coefficient of volume compressibility $\left(m_{v}\right)$ located at the end point of each stress stage. In summary, increased normal pressure, no produced uniform changes in the coefficient of volume compressibility of the soil specimens so that with small normal stresses, an alternate decreasing-increasing trend was observed in the coefficient of volume compressibility, which continued up to $40 \mathrm{kPa}$ vertical stress. However, from $80 \mathrm{kPa}$ effective normal stress, an increasing trend was observed in the coefficient of volume compressibility of the soil specimens. Based on Figure 6, the average value of coefficient of volume change of untreated and stabilized soil was found to be 0.55 and $0.43 \mathrm{~m}^{2} / \mathrm{MN}$, respectively.

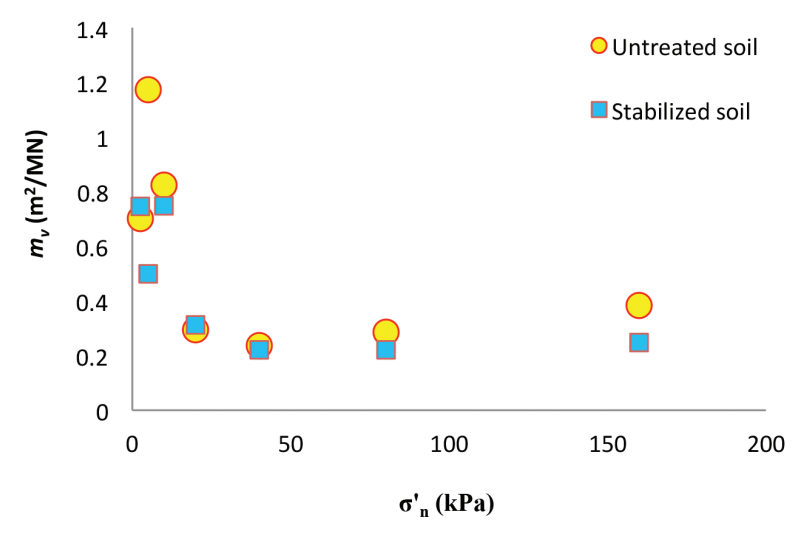

FIGURE 6 . The $m_{v} / \sigma^{\prime}$ relationships of the untreated and stabilized soil specimens

The variations of the void ratio as a function of the change of effective stress are plotted in the logarithmic scale as shown in Figure 7. Through such graphical plot, the value of compressibility index and swelling index of the soil over a normal stress range can be determined. Based on Figure 7, the compression and recompression due to loading and unloading process in 1D consolidation tests are indicated. It can be observed from both figures that the volume of the soil specimen gradually reduced due to the loading process as the effect of loading on the soil specimen is to squeeze out pore water. The result of unloading from the soil specimen is swelling. After unloading from point $\mathrm{M}$, it followed the swelling line until it reached to point $\mathrm{N}$. From e/log $\sigma^{\prime}$ curve, the swelling index $\left(C_{s}\right)$ can be determined. The swelling behavior of the soft clay must be characterized in order to gage the risk of unloading of the soil at the site. Reloading would cause recompression as shown on the graph of Figure 7. The compressibility index is the slope of the NCL and the average slope of the swelling/ recompression curve (SRL) is referred to as the swelling 
index. Based on the e/log $\sigma$ ' curve, the compressibility index $\left(C_{c}\right)$ of the untreated and stabilized soil specimens was found to be 0.170 and 0.103 , respectively. Besides, the average value of the recompression index of the untreated and stabilized soil specimens was discovered to be 0.036 and 0.027 , respectively.

According to Terzaghi and Peck (1967), the compressibility index $\left(C_{c}\right)$ of the normally consolidated clay can be calculated using the empirical (1) as follows.

$$
C_{c}=0.009(L L-10) .
$$

Besides, Huat et al. (1995) have presented an empirical expression (2) for the soft clay located in Selangor, Malaysia.

$$
C c=0.005(L L+71.8) .
$$

With regard to (1) and (2) the compressibility index of the untreated and stabilized soil specimens was calculated as shown in Table 3. By inspecting the information of Table 3 , it can be pointed that the reliability of (1) is more satisfied when compared to (2). In contrast, the compression index obtained by Horpibulsuk et al. (2011) for high plasticity Bangkok clay $(\mathrm{CH})$ is 0.4 . Such value of compression index is very close to that of determined by (1). In addition, Nishida (1956) has presented an empirical expression to determine the approximate value of the $C_{c}$ for clay soil (3).

$$
C_{C}=1.15\left(e_{0}-0.35\right) \text {. }
$$

By employing (3), the compression index of the untreated and stabilized soil was determined to be 0.414 and 0.299 , respectively.

The axial strain- $\log \sigma_{n}$ relationships of the untreated and stabilized soil are established in Figure 8. From Figure 8 , it can be seen the slight convex curves that demonstrate strain of the test specimens under application of various normal stresses. As shown on the graphs of Figure 8, the convex curves follow upon reaching the virgin line. Based on Figure 8, stabilization of the soil with cement and peat ash reduced the vertical displacement due to formation of cementation products that function as a binder and clog the soil particles. Indeed, peat ash played a key role at

(a)

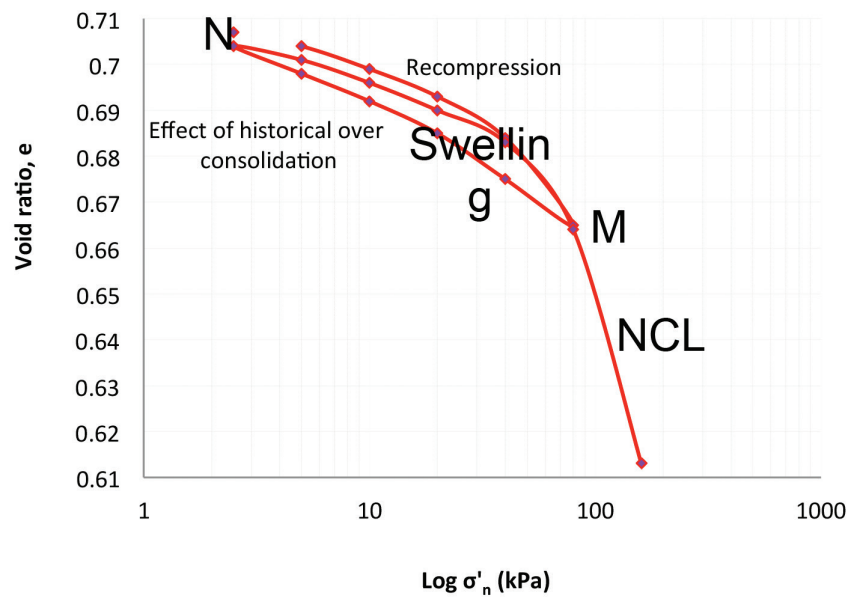

(b)

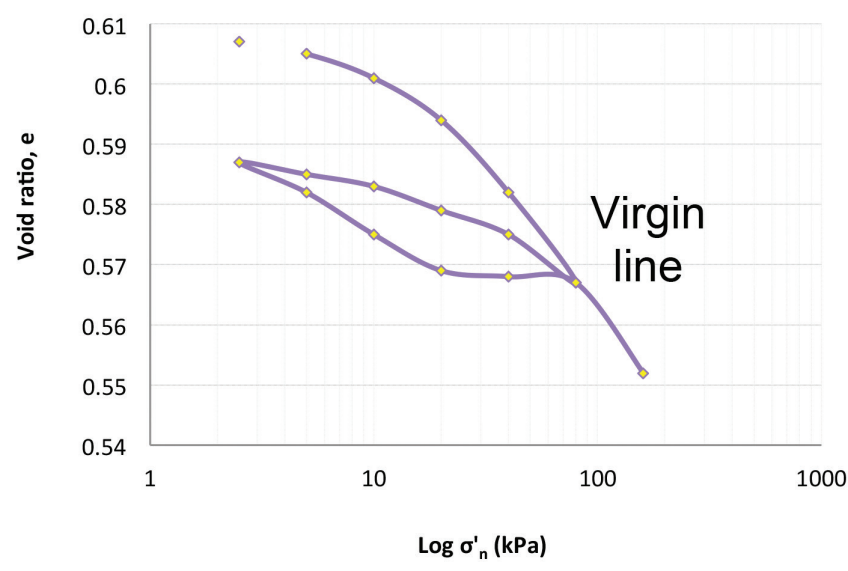

FIGURE 7. Swelling and Recompression curves of (a) untreated and (b) stabilized clay 
TABLE 3. Average values of the compressibility index

\begin{tabular}{ccc}
\hline Description & \multicolumn{2}{c}{ Compressibility index } \\
& Untreated soil & Stabilized soil \\
\hline Laboratory 1D consolidation test & 0.17 & 0.103 \\
$C_{c}=0.009(L L-10)$ & 0.411 & 0.431 \\
$C_{c}=0.005(L L+71.8)$ & 0.637 & 0.648 \\
\hline
\end{tabular}

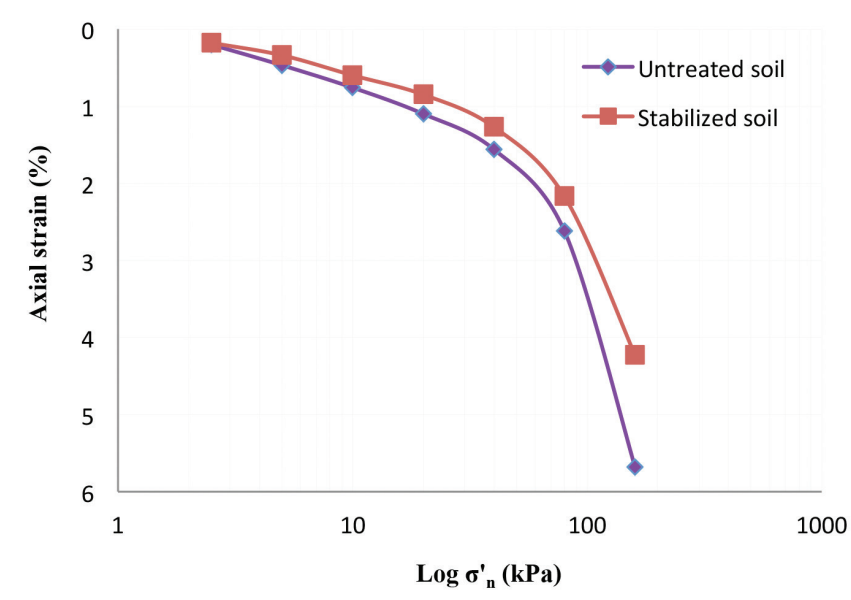

FIGURE 8. Axial strain versus pressure of the soil specimens

inducing secondary pozzolanic activity of the stabilized soil specimen. Since, pozzolanic materials in the form of peat ash are capable to react with calcium hydroxide released from cement hydrolysis to produce secondary cementation products (Wong et al. 2013).

The results of $1 \mathrm{D}$ consolidation tests (i.e. compression and recompression) of the untreated and stabilized soil specimens are summarized in Tables 4 and 5. The elastic parameters derived from 1D dimensional compression tests can contribute to analyse the settlement of road embankments. To perform the recompression tests, each vertical load was held constant for $24 \mathrm{~h}$ before the application of the next loading increment. At the end of the loading period for $80 \mathrm{kPa}$, the vertical load was removed and the specimen allowed swelling for $24 \mathrm{~h}$. The amount of consolidation settlement was estimated from the soil e/ $\sigma$ ' curve. From the results of 1D consolidation tests, the average values of void ratio were obtained as presented in Table 4. By analyzing the results, the vertical strain of the stabilized soil reduced by almost $33 \%$ when compared

TABLE 4. Results of 1D consolidation compression tests

\begin{tabular}{cccc}
\hline & Pressure $(\mathrm{kPa})$ & Void ratio $\left(\mathrm{e}=\mathrm{e}_{0}-\Delta \mathrm{e}\right)$ & Axial strain $(\%)$ \\
\cline { 2 - 4 } & 0 & 0.710 & 0 \\
& 2.5 & 0.707 & 0.18 \\
Untreated soil & 5 & 0.702 & 0.47 \\
& 10 & 0.695 & 0.88 \\
& 20 & 0.690 & 1.17 \\
& 40 & 0.682 & 1.58 \\
& 80 & 0.664 & 2.62 \\
& 160 & 0.613 & 5.68 \\
\cline { 2 - 4 } Stabilized soil & 0 & 0.609 & 0 \\
& 2.5 & 0.606 & 0.19 \\
& 5 & 0.604 & 0.37 \\
& 10 & 0.598 & 0.72 \\
& 40 & 0.593 & 0.98 \\
& 80 & 0.586 & 1.47 \\
& 160 & 0.572 & 2.37 \\
& & 0.541 & 4.28 \\
\hline
\end{tabular}


TABLE 5. Results of 1D consolidation recompression tests



to that of untreated. Besides, the average value of void ratio of the stabilized soil improved about $16 \%$. It can be observed from Table 5 that a $1.14 \mathrm{~mm}$ compression settlement of the untreated soil reached by the clay under a consolidation stress of $160 \mathrm{kPa}$. Likewise, a $0.86 \mathrm{~mm}$ compression settlement of the stabilized soil happened under a consolidation stress of $160 \mathrm{kPa}$.

The 1D consolidation test parameters and coefficients are tabulated in Table 6 . The average value of $C_{v}$ was obtained by applying Casagrande method. Generally, the coefficients of consolidation and volume change are the main parameters in virgin compression. To evaluate consolidation settlement the coefficient of permeability of the soil specimen must be taken into consideration. It has to be noted that the rate at which consolidation occurs mainly depends on the permeability of the soil and the length of drainage path. Results of coefficient of permeability of the untreated and stabilized clay measured by laboratory 1D consolidation tests are tabulated in Table 6. From the data of Table 6 , the average value of $k_{v}$ of the untreated clay was determined to be $0.84 \times 10^{-10} \mathrm{~m} \mathrm{~s}^{-1}$. After analyzing Table 6 , the average value of coefficient of permeability of the stabilized clay was found to be $0.54 \times 10^{-10} \mathrm{~ms}^{-1}$. Thus, the addition of $18 \%$ cement, $2 \%$ peat ash and $5 \%$ silica sand reduced the coefficient of permeability of the stabilized soil by almost $36 \%$ when compared to that of untreated. This is due to the fineness of peat ash that enabled the clay to bring filler and pozzolanic effect on cemented soil, so that the pore spaces of the soil was refined, thus improving the soil properties. This resulted in a denser state of the soil under consolidation. The similar pattern and behavior of clay soil can be found in the study of Taha et al. (2000). According to Taha et al. (2000), marine clay and river clay were tested under $1 \mathrm{D}$ consolidation tests. The compression index of marine clay obtained by Taha et al. (2000) is very close to that of investigated in current research. 
TABLE 6. Results of 1D consolidation tests of the untreated and stabilized soil specimens

\begin{tabular}{|c|c|c|c|c|}
\hline & Pressure $(\mathrm{kPa})$ & $c_{v}\left(\mathrm{~m}^{2} /\right.$ year $)$ & $m_{v}\left(\mathrm{~m}^{2} / \mathrm{MN}\right)$ & $k_{v}\left(\mathrm{~ms}^{-1}\right)$ \\
\hline \multirow{7}{*}{ Untreated soil } & 2.5 & 1.34 & 0.702 & $2.9 \times 10^{-10}$ \\
\hline & 5 & 0.31 & 1.172 & $1.13 \times 10^{-10}$ \\
\hline & 10 & 0.27 & 0.823 & $0.69 \times 10^{-10}$ \\
\hline & 20 & 0.36 & 0.295 & $0.33 \times 10^{-10}$ \\
\hline & 40 & 0.08 & 0.237 & $0.06 \times 10^{-10}$ \\
\hline & 80 & 0.63 & 0.268 & $0.53 \times 10^{-10}$ \\
\hline & 160 & 0.20 & 0.383 & $0.24 \times 10^{-10}$ \\
\hline \multirow{7}{*}{ Stabilized soil } & 2.5 & 0.51 & 0.746 & $1.18 \times 10^{-10}$ \\
\hline & 5 & 0.41 & 0.498 & $0.64 \times 10^{-10}$ \\
\hline & 10 & 0.36 & 0.748 & $0.84 \times 10^{-10}$ \\
\hline & 20 & 0.41 & 0.313 & $0.40 \times 10^{-10}$ \\
\hline & 40 & 0.35 & 0.220 & $0.24 \times 10^{-10}$ \\
\hline & 80 & 0.31 & 0.221 & $0.21 \times 10^{-10}$ \\
\hline & 160 & 0.33 & 0.247 & $0.25 \times 10^{-10}$ \\
\hline
\end{tabular}

\section{CONCLUSION}

Laboratory 1D consolidation tests were conducted to evaluate compressibility of the Wetlands clay due to stabilization with cement, peat ash and silica sand. The results of $1 \mathrm{D}$ consolidation tests were analyzed on the basis of compression settlement of the soil specimens. From the results of this paper the following conclusions are drawn. Based on the results it is concluded that Wetlands clay is normally consolidated. Peat ash affects the soil properties by improving the matrix of the stabilized soil. This phenomenon occurred because the cementation products fill up the soil pore spaces, thus creating a binding effect on the soil particles. The compaction coupled with stabilization so that the pore spaces of the soil were refined, thus improving the soil properties. This resulted in a denser state of the stabilized soil after compaction. It can be concluded that consolidation settlement of the stabilized soil specimen corresponding to $160 \mathrm{kPa}$ effective vertical stress improved by almost $33 \%$ when compared with that untreated. It is evident that soil stabilization improved the coefficient of permeability of the soil by almost $56 \%$.

\section{ACKNOWLEDGEMENTS}

The work presented in this paper was carried out at Universiti Tenaga Nasional (UNITEN) during the doctoral studies of the first author. The authors would like to thank all the parties involved in this study.

\section{REFERENCES}

Abou-Taleb, A.N., Musaiger, A.O. \& Abdelmoneim, R.B. 1995. Health status of cement workers in the United Arab Emirates. J. R. Soc. Health 115: 378-381

ASTM D2974-14. 2014. Standard Test Methods for Moisture, Ash, and Organic Matter of Peat and Other Organic Soils. West Conshohocken, PA: ASTM International.

ASTM D2435-04. 2011. Standard Test Methods for OneDimensional Consolidation Properties of Soils Using Incremental Loading. West Conshohocken, PA: ASTM International.
Bujang, B.K.H., Kazemian, S., Prasad, A. \& Barghchi, M. 2011. State of an art review of peat: General perspective. International Journal of the Physical Sciences 6: 1988-1996.

Baghdadi, Z.A. 1990. Utilization of kiln dust in clay stabilization. Eng. Sci., Jeddah, Scientific Publication Center, King Abdul Aziz University 2: 153-163.

Collins, R.J. \& Emery, J.J. 1983. Kiln Dust-Fly Ash System for Highway Bases and Subbases. Federal Highway Administration Report FHWA/RD-82/167. US Department of Transportation, Washington, DC.

Eberemu, A.O. 2015. Compressibility characteristics of compacted lateritic soil treated with bagasse ash. Jordan Journal of Civil Engineering 9: 214-228.

Horpibulsuk, S., Rachan, R. \& Suddeepong, A. 2011. Assessment of strength development in blended cement admixed Bangkok clay. Construction and Building Materials 25: 1521-1531.

Huat, B.B.K., Othman, K. \& Jaffar, A.A. 1995. Geotechnical properties of Malaysian marine clays. J. Inst. Engineers Malaysia 56: 23-33.

Isaia, G.C., Gastaldini, A.L.G. \& Moraes, R. 2003. Physical and pozzolanic action of mineral additions on the mechanical strength of high-performance concrete. Cement and Concrete Composites 25: 69-76.

Mousavi, S.E. \& Wong, L.S. 2015. Performance of compacted and stabilized clay with cement, peat ash and silica sand. Jordan Journal of Civil Engineering 9: 20-32.

Maio Di, C., Santoli, L. \& Schiavone, P. 2004. Volume change behaviour of clays: The influence of mineral composition, pore fluid composition and stress state. Mechanics of Materials 36: 435-451.

Nishida, Y. 1956. A brief note on compression index of soils. Journal of Soil Mechanics and Foundations Division, ASCE, 82, SM3, 1027-1-1027-14.

Purwana, Y.M. \& Nikraz, H. 2013. The correlation between the CBR and shear strength in unsaturated soil conditions. International Journal of Transportation Engineering 1: 211-222.

Rehan, R. \& Nehdi, M. 2005. Carbon dioxide emissions and climate change: Policy implications for the cement industry. Environmental Science and Policy 8: 105-114.

Schiffman, R.L., Pane, V. \& Gibson, R.E. 1984. The theory of one-dimensional consolidation of saturated clays: IV-An overview of the non-linear finite strain sedimentation and consolidation. ASCE 1-29. 
Taha, M.R., Ahmed, J. \& Asmirza, S. 2000. One dimensional consolidation of Kelang clay. Pertanika Journal of Science and Technology 8: 19-29.

Terzaghi, K. \& Peck, R.B. 1967. Soil Mechanics in Engineering Practice. 2nd ed. New York: John Wiley and Sons.

Terzaghi, K. 1943. Theoretical Soil Mechanics. New York: John Wiley \& Sons, Inc.p. 265.

Velosa, A.L. \& Cachim, P.B. 2009. Hydraulic-lime based concrete: Strength development using a pozzolanic addition and different curing conditions. Construction and Building Materials 23: 2107-2111

Wong, L.S., Hashim, R. \& Ali, F. 2013. Improved strength and reduced permeability of stabilized peat: Focus on application of kaolin as a pozzolanic additive. Construction and Building Materials 40: 783-792.
Yilmaz, Y. \& Ozaydin, V. 2013. Compaction and shear strength characteristics of colemanite ore waste modified active belite cement stabilized high plasticity soil. Engineering Geology 155: 45-53.

Department of Civil Engineering, College of Engineering Universiti Tenaga Nasional, IKRAM-UNITEN Road 43000 Kajang, Selangor Darul Ehsan Malaysia

*Corresponding author; email: mousavi@khiau.ac.ir

Received: 7 August 2015

Accepted: 22 April 2016 